\title{
PENGARUH PERSEPSI DOSEN MENGENAI STANDAR MUTU PROSES PEMBELAJARAN TERHADAP PELAKSANAAN PROSES PEMBELAJARAN DI INSTITUT SENI BUDAYA INDONESIA (ISBI) BANDUNG ${ }^{1}$
}

\author{
Aceng Lukman', Lukman M. Baga ${ }^{3}$, Farit M. Afendi ${ }^{4}$ \\ email: alukman88@.gmail.com / lukmanmb@yahoo.com \\ fmafendi@gmail.com \\ Manajemen Pendidikan Tinggi Institut Pertanian Bogor
}

\begin{abstract}
The increasing number of universities, both public and private universities have made the competition among universities in Indonesia is getting tighter. Universities that want to survive and win the competition are required to perform continuous quality improvement (CQI). The purpose of this study was to describe the factors that influence the perception of lecturers of ISBI Bandung on the quality standard of the learning process and to figure out the influence of perception of lecturer of ISBI Bandung regarding the quality standard of the learning process on the implementation of the learning process. Data collection methods used in this study were interviews through a questionnaire. The questions in the questionnaire were made in the form of a statement that is measured based on the Likert scale. The data analysis using Structural Equation Modeling (SEM) with Partial Least Square (PLS) approach. The result showed that faculty perception of the quality standard of learning processes affect the implementation of learning process with a contribution of $29.6 \%$.

Keywords: perception, quality standards, the learning process, implementation, Structural Equation Modeling (SEM)
\end{abstract}

\begin{abstract}
ABSTRAK
Semakin meningkatnya jumlah perguruan tinggi di Indonesia telah membuat peta persaingan antar perguruan tinggi semakin ketat. Perguruan Tinggi yang ingin memenangkan persaingan dituntut untuk melakukan continuous quality improvement (CQI). Tujuan dari penelitian ini adalah untuk mendeskripsikan faktor-faktor yang memengaruhi persepsi dosen ISBI Bandung mengenai standar mutu proses pembelajaran dan mengetahui pengaruh persepsi dosen ISBI Bandung mengenai standar mutu proses pembelajaran terhadap pelaksanaan proses pembelajaran. Metode pengumpulan data yang digunakan dalam penelitian ini adalah wawancara melalui kuesioner. Pertanyaan-pertanyaan dalam kuesioner dibuat dalam bentuk pernyataan yang diukur berdasarkan skala Likert. Analisis data menggunakan Structural Equation Modeling (SEM) dengan pendekatan Partial Least Square (PLS). Hasil penelitian menunjukkan bahwa persepsi dosen mengenai standar mutu proses pembelajaran memengaruhi pelaksanaan proses pembelajaran dengan kontribusi sebesar 29,6\%.
\end{abstract}

Kata kunci: persepsi, standar mutu proses pembelajaran, implementasi, Structural Equation Modeling (SEM)

\section{PENDAHULUAN}

Setiap organisasi selalu dihadapkan pada perubahan, baik perubahan eksternal maupun perubahan internal. Perguruan Tinggi sebagai sebuah organisasi penyelenggara pendidikan tinggi tidak terlepas dari kondisi tersebut. Hal ini sesuai dengan pernyataan berikut, "Industries, like higher education, once considered safe from competitive forces are now finding themselves subjected to competition for the resources they once took for granted" (Richardson et al. 1995:9). Semakin meningkatnya jumlah perguruan tinggi baik swasta maupun negeri dan masuknya perguruan tinggi asing telah membuat peta persaingan antar perguruan tinggi semakin ketat. Perguruan Tinggi yang ingin bertahan dan memenangkan persaingan dituntut untuk melakukan continuous quality improvement (CQI) atau peningkatan mutu/ kualitas secara terus menerus (berkelanjutan). Hal tersebut sesuai dengan pernyataan berikut, "the college choose quality management to distinguish itself better from its competitors and to compete better in the marketplace." (Mergen et al. 2000:346).

Pemerintah menerbitkan Peraturan Pemerintah Republik Indonesia nomor 13 tahun 2015 tentang standar nasional pendidikan tinggi untuk menjamin standar mutu pendidikan tinggi di Indonesia. Standar nasional pendidikan tinggi mencakup standar nasional pendidikan, ditambah dengan standar nasional penelitian, dan standar 
nasional pengabdian kepada masyarakat. Standar nasional pendidikan meliputi standar isi, standar proses, standar kompetensi lulusan; standar pendidik dan tenaga kependidikan; standar sarana dan prasarana; standar pengelolaan; standar pembiayaan, dan standar penilaian.

Standar proses dapat dikatakan merupakan inti dari semua standar tersebut, hal ini sesuai dengan pernyataan Ahuja (2013:419) yang menyatakan bahwa pengajaran merupakan tulang punggung dari setiap sistem pendidikan. Tujuan pengajaran adalah transmisi pengetahuan dari pendidik kepada peserta didik. Di luar dari proses yang terjadi di ruang kuliah, cara penyampaian materi dapat disampaikan melalui cara lain yang lebih inovatif, misalnya diskusi, bermain peran, dan metode simulasi. Metode pengajaran diselaraskan dengan tujuan pembelajaran yang akan memfasilitasi proses pembelajaran menjadi lebih baik.

Proses pembelajaran di perguruan tinggi sangat erat kaitannya dengan tenaga pendidik atau dosen. Pasal 1 ayat 14 undangundang (UU) no. 12 tahun 2012 tentang pendidikan tinggi menyatakan bahwa dosen adalah pendidik profesional dan ilmuwan dengan tugas utama mentransformasikan, mengembangkan, dan menyebarluaskan Ilmu Pengetahuan dan Teknologi melalui Pendidikan, Penelitian, dan Pengabdian kepada Masyarakat. Melihat pentingnya tugas serta fungsi dosen dalam proses pembelajaran maka persepsi dosen mengenai standar mutu proses pembelajaran tentunya juga sangat penting untuk dikaji.

Manajemen mutu merupakan hal yang sudah sejak lama digunakan dalam dunia usaha, dan bidang pendidikan khususnya pendidikan tinggi mengadopsi sistem tersebut. Namun perdebatan muncul pada awal implementasi manajemen mutu di perguruan tinggi, seperti yang dikemukakan oleh Owlia dan Aspinwall (1997:8) berikut ini:

While TQM as a successful managerial strategy is generally accepted in commercial organizations, its role in the public sector, especially in higher education, is still controversial. From a theoretical point of view, customer orientation is a more problematic principle of TQM when applied to universities. This is because of the special nature of many academics whose motivation for work is often independent of market issues. Although this spirit should be regarded as having some value in scientific environments, it may also be detrimental. Disregarding the market, on the other hand, has the danger of ignoring the real needs of consumers.

Menurut pasal 1 ayat 1 Permendikbud Republik Indonesia no. 50 tahun 2014 tentang sistem penjaminan mutu pendidikan tinggi, yang dimaksud dengan mutu pendidikan tinggi adalah tingkat kesesuaian antara penyelenggaraan pendidikan tinggi dengan standar pendidikan tinggi yang terdiri atas standar nasional pendidikan tinggi dan standar pendidikan tinggi yang ditetapkan oleh perguruan tinggi. Adapun ayat 2 menjelaskan pengertian Sistem Penjaminan Mutu pendidikan tinggi adalah kegiatan sistemik untuk meningkatkan mutu pendidikan tinggi secara berencana dan berkelanjutan. Terdapat empat kata kunci dalam pengertian Sistem Penjaminan Mutu pendidikan tinggi dalam Permendikbud tersebut, yakni sistemik, mutu, berencana, dan berkelanjutan.

Adapun mengenai persepsi, Walgito (2010:99) mengemukakan bahwa persepsi merupakan suatu proses yang didahului oleh proses penginderaan, yaitu merupakan proses diterimanya stimulus oleh individu melalui alat indera atau juga disebut proses sensoris. Faktor-faktor yang memengaruhi persepsi meliputi fisiologi, perhatian, intensitas stimulus, ukuran stimulus, perubahan stimulus, ulangan stimulus, dan kekontrasan stimulus. Hasil penelitian Irawan (2015) 
mengemukakan bahwa persepsi sebagai bagian dari faktor psikologi memberi pengaruh terhadap kinerja pegawai.

\section{METODE PENELITIAN}

Lokasi penelitian adalah di Institut Seni Budaya Indonesia (ISBI) Bandung. Adapun metode pengumpulan data yang digunakan dalam penelitian ini adalah metode wawancara melalui instrumen kuesioner yang menyajikan sejumlah daftar pertanyaan. Pertanyaan-pertanyaan dalam kuesioner dibuat dalam bentuk pernyataan yang diukur berdasarkan skala Likert dan dalam bentuk pertanyaan khususnya yang berkaitan dengan masalah demografi responden. Daftar pernyataan serta pertanyaan yang diajukan kepada responden berupa pertanyaan tertutup. Daftar pernyataan serta pertanyaan tertutup digunakan untuk memperoleh data yang merepresentasikan indikator-indikator dari tiap dimensi variabel yang digunakan

\section{Tabel 1}

Daftar jumlah dosen keseluruhan dan dosen aktif ISBI Bandung

\begin{tabular}{clccc}
\hline No. & \multicolumn{1}{c}{ Program Studi } & $\begin{array}{c}\text { Jumlah } \\
\text { Dosen }\end{array}$ & $\begin{array}{c}\text { Jumlah } \\
\text { Dosen Aktif }\end{array}$ & Jumlah Sampel \\
\hline 1 & Seni Karawitan & 44 & 40 & 28 \\
2 & Seni Rupa Murni & 9 & 8 & 6 \\
3 & Seni Tari & 43 & 41 & 29 \\
4 & Seni Teater & 32 & 31 & 22 \\
5 & Angklung dan Musik Bambu & 8 & 8 & 6 \\
6 & Tata Rias dan Busana & 9 & 8 & 6 \\
7 & Televisi dan Film & 8 & 8 & 6 \\
8 & Seni Rupa & 17 & 15 & 11 \\
\hline & Total & 170 & 159 & 114 \\
\hline
\end{tabular}

Sumber: subag kepegawaian ISBI Bandung Desember (2015)

Penentuan jumlah sampel dari keseluruhan prodi dihitung dengan menggunakan rumus Slovin sebagai berikut:

$\mathrm{n}=\mathrm{N}$

$$
1+\mathrm{Ne}^{2}
$$

ket:

$\mathrm{N}=$ jumlah populasi penelitian

$\mathrm{n}=$ jumlah sampel penelitian

$\mathrm{e}=$ nilai kritis (batas ketelitian)

$\mathrm{n}=159 / 1+159(0,05)^{2}$

$=113,77$ dibulatkan menjadi 114 orang.

Berdasarkan total sampel sebanyak 114 dalam penelitian ini, selain itu juga untuk menggali informasi mengenai jenis kelamin, usia, status pernikahan, pendidikan, masa kerja, kepangkatan, jabatan, dan yang berkaitan dengan tunjangan sertifikasi dosen.

Teknik pengambilan sampel yang digunakan adalah metode pengambilan sampel acak terstratifikasi (stratified random sampling). Teknik pengambilan sampel acak terstratifikasi adalah metode pemilihan sampel dengan cara membagi populasi ke dalam kelompok-kelompok yang homogen yang disebut strata, dan kemudian sampel diambil secara acak dari tiap strata (Sugiarto et al. 2001). Populasi penelitian ini adalah seluruh dosen ISBI Bandung sebanyak 170 orang yang dikelompokkan ke dalam delapan program studi (prodi)/strata. Data jumlah dosen ISBI Bandung dan dosen aktif bulan Desember 2015 serta jumlah sampel penelitian dapat dilihat pada tabel 1 .

dosen, jumlah sampel per prodi dihitung secara proporsional, yakni jumlah dosen aktif per prodi dibagi jumlah total dosen aktif dikali jumlah total sampel.

Data yang telah dikumpulkan, selanjutnya diolah agar memiliki makna yang berguna untuk memecahkan masalah yang diteliti. Untuk data-data kualitatif dilakukan analisis deskriptif, sedangkan pengolahan data kuantitatif dilakukan dengan terlebih dahulu memberikan kode (coding) untuk menyeragamkan data. Pengolahan data 
dilakukan dengan menggunakan teknik SEM dengan pendekatan PLS dengan bantuan Software SmartPLS versi 2.0. Adapun untuk keperluan penolakan atau penerimaan hipotesis, penulis menggunakan taraf signifikansi 5 persen $(\alpha=0,05)$.

\section{HASIL DAN PEMBAHASAN}

\section{Pengujian Kualitas Instrumen Penelitian}

Sebelum data hasil penelitian diolah, terlebih dahulu dilakukan pengujian kelayakan terhadap kualitas alat ukur penelitian (kuesioner) yang digunakan untuk membuktikan apakah kuesioner yang digunakan memiliki ketepatan (validity) dan konsistensi (reliability) untuk digunakan sebagai alat ukur penelitian.

\section{Uji Validitas}

Uji validitas ini dimaksudkan untuk mengukur valid atau tidaknya suatu pertanyaan dalam kuesioner. Valid berarti instrumen tersebut dapat digunakan untuk mengukur apa yang seharusnya diukur (Sugiyono 2014:121). Suatu pertanyaan dikatakan sahih atau valid apabila pertanyaan pada kuesioner mampu mengungkapkan sesuatu yang hendak diukur oleh kuesioner tersebut dan memiliki r hitung

Tabel 2

Rekapitulasi hasil pengujian reliabilitas

\begin{tabular}{cccc}
\hline Variabel & Koefisien Reliabilitas & Titik Kritis & Keterangan \\
& & & \\
\hline Persepsi (X) & 0,965 & 0,700 & Reliabel \\
Implementasi (Y) & 0,916 & 0,700 & Reliabel \\
\hline
\end{tabular}

Sumber: Hasil pengolahan data menggunakan SPSS

Pada tabel 2 dapat dilihat kedua variabel memiliki nilai cronbach's alpha lebih besar dari 0,70, dengan demikian dinyatakan reliabel. Berdasarkan hasil pengujian validitas dan reliabilitas yang telah diuraikan di atas, dapat disimpulkan bahwa seluruh pertanyaan yang digunakan dalam penelitian ini sudah teruji kesahihan (validity) dan konsistensinya (reliability) untuk dapat digunakan sebagai alat ukur penelitian.

Untuk melihat tanggapan responden yang lebih besar dari nilai $r$ tabel untuk jumlah responden 30 yakni sebesar 0,361 (Yamin dan Kurniawan 2009:284). Berdasarkan hasil perhitungan diketahui bahwa seluruh pertanyaan yang digunakan untuk mengukur kedua variabel memiliki nilai $r$ hitung yang lebih besar dari 0,361 (nilai $r$ tabel), dengan demikian seluruh pertanyaan tersebut dinyatakan valid.

\section{Uji Reliabilitas}

Pengujian reliabilitas ini dimaksudkan untuk menguji konsistensi alat ukur penelitian. Pengukuran yang memiliki reliabilitas tinggi disebut sebagai pengukuran yang reliabel (Azwar 2004:4). Suatu kuesioner dikatakan reliabel atau handal jika jawaban seseorang terhadap pernyataan adalah konsisten atau stabil dari waktu ke waktu (Ghozali 2011). Dalam penelitian ini, untuk menguji konsistensi alat ukur penelitian digunakan metode cronbach's alpha. Suatu konstruk atau variabel dapat diterima apabila memilki koefisien reliabilitas yang lebih besar dari 0,70 (Yamin dan Kurniawan 2009:284). Rekapitulasi hasil perhitungan koefisien reliabilitas dapat dilihat pada tabel 2 . terhadap setiap variabel dan sub variabel yang diajukan dalam kuesioner, dapat dilihat dari nilai prosentase skor maksimum yang diperoleh dari hasil pembagian antara skor aktual (skor hasil penjumlahan dari jawaban responden) dengan skor maksimum dikali 100\%. Untuk mempermudah dalam menginterpretasikan hasil penilaian responden, peneliti mengacu pada kriteria prosentase skor tanggapan responden seperti yang dapat dilihat pada tabel 3 . 
Tabel 3

Kriteria prosentase skor tanggapan responden terhadap skor maksimum

\begin{tabular}{ccc}
\hline No. & \% Jumlah Skor & Kriteria \\
\hline 1. & $20,00-36,00$ & Sangat Tidak Baik \\
2. & $36,01-51,00$ & Tidak Baik \\
3. & $51,01-68,00$ & Cukup Baik \\
4. & $68,01-84,00$ & Baik \\
5. & $84,01-100$ & Sangat Baik \\
\hline
\end{tabular}

Sumber: Narimawati (2007)

Berdasarkan hasil penelitian diketahui bahwa skor aktual untuk variabel persepsi sebesar 6280 dan skor maksimum sebesar 8550 dengan nilai prosentase yang diperoleh sebesar 74,62\%, termasuk dalam kategori baik berada pada rentang interval 68,01 - 84,00. Jadi, dapat disimpulkan bahwa tanggapan responden terhadap variabel persepsi dosen ISBI Bandung tergolong baik.

Adapun untuk tanggapan responden terhadap variabel implementasi diketahui bahwa skor aktual untuk variabel implementasi sebesar 8108 dan skor maksimum sebesar 10260 dengan nilai prosentase yang diperoleh sebesar 79,03\%, termasuk dalam kategori baik berada pada rentang interval 68,01 - 84,00. Jadi, dapat disimpulkan bahwa tanggapan responden terhadap variabel implementasi proses pembelajaran di ISBI Bandung tergolong baik. Meski demikian upaya-upaya untuk terus meningkatkan kualitas implementasi proses pembelajaran di ISBI Bandung khususnya dalam proses pembelajaran harus terus dilakukan.

\section{Analisis Data dan Pengujian Hipotesis}

Selanjutnya hipotesis konseptual yang sebelumnya diajukan akan diuji dan dibuktikan dengan menggunakan uji statistik. Hipotesis konseptual yang diajukan adalah diduga adanya pengaruh dari persepsi terhadap implementasi proses pembelajaran di ISBI Bandung. Metode statistik yang digunakan untuk menguji hipotesis tersebut adalah structural equation modelling (SEM) menggunakan partial least square (PLS). Model yang diujikan dalam penelitian ini dapat dilihat pada gambar 1 .

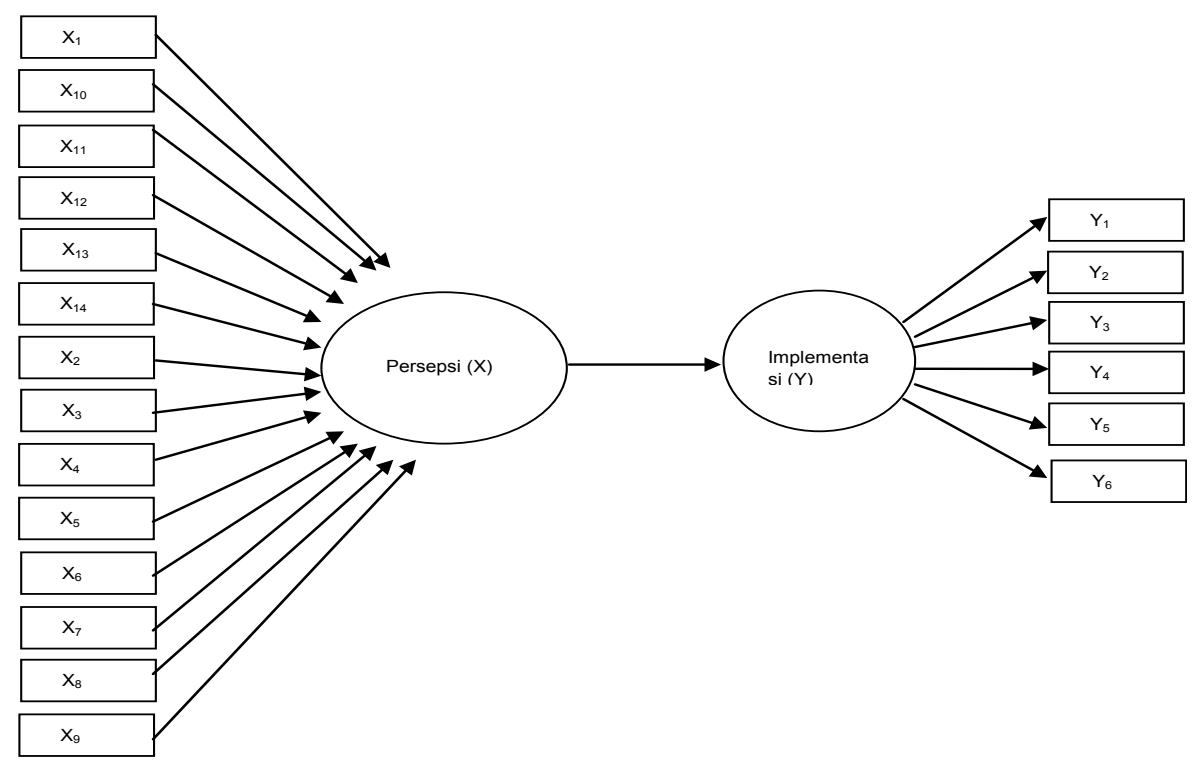

Gambar 1

Model penelitian 
Keterangan :

$\mathrm{X}=$ Persepsi

$\mathrm{X}_{\mathrm{*}_{1}} \quad=$ Standar mutu

$\mathrm{X}_{._{2}}=$ Perhatian terhadap standar mutu

$\mathrm{X}_{3} \quad=$ Mencari informasi tentang standar mutu

$\mathrm{X}_{{ }_{4}} \quad=$ Mengikuti perkembangan standar mutu

$\mathrm{X}_{{ }_{5}} \quad=$ Memerlukan standar mutu

$\mathrm{X}_{6}{ }_{6}=$ Isi standar mutu

$\mathrm{X}_{.7} \quad=$ Standar mutu merupakan instrumen penting

$\mathrm{X}_{8} \quad=$ Standar mutu dapat meningkatkan proses pembelajaran

$\mathrm{X}_{.9} \quad=$ Standar mutu dapat meningkatkan kompetensi mahasiswa

$\mathrm{X}_{.10} \quad=$ Pengalaman mengenai standar mutu
$\mathrm{X}_{.11}=$ Intensitas standar mutu

$\mathrm{X}_{.12}=$ Perubahan standar mutu

$\mathrm{X}_{.13}=$ Frekuensi standar mutu

$\mathrm{X}_{.14}=$ Perbedaan standar mutu

$\mathrm{Y}^{.14}=$ Implementasi

$\mathrm{Y}_{{ }_{1}} \quad=$ Menyediakan silabus

$\mathrm{Y}_{._{2}} \quad=$ Menyediakan bahan ajar

$\mathrm{Y}_{3} \quad=$ Menyediakan media pembelajaran

$\mathrm{Y}_{4}=$ Mengisi berita acara perkuliahan

$\mathrm{Y}_{\mathrm{V}_{5}} \quad=$ Perkuliahan tepat waktu

$\mathrm{Y}_{.6} \quad=$ Membantu pengembangan diri mahasiswa

Hasil perhitungan dari keseluruhan model menggunakan SmartPLS dapat dilihat pada gambar 2 .

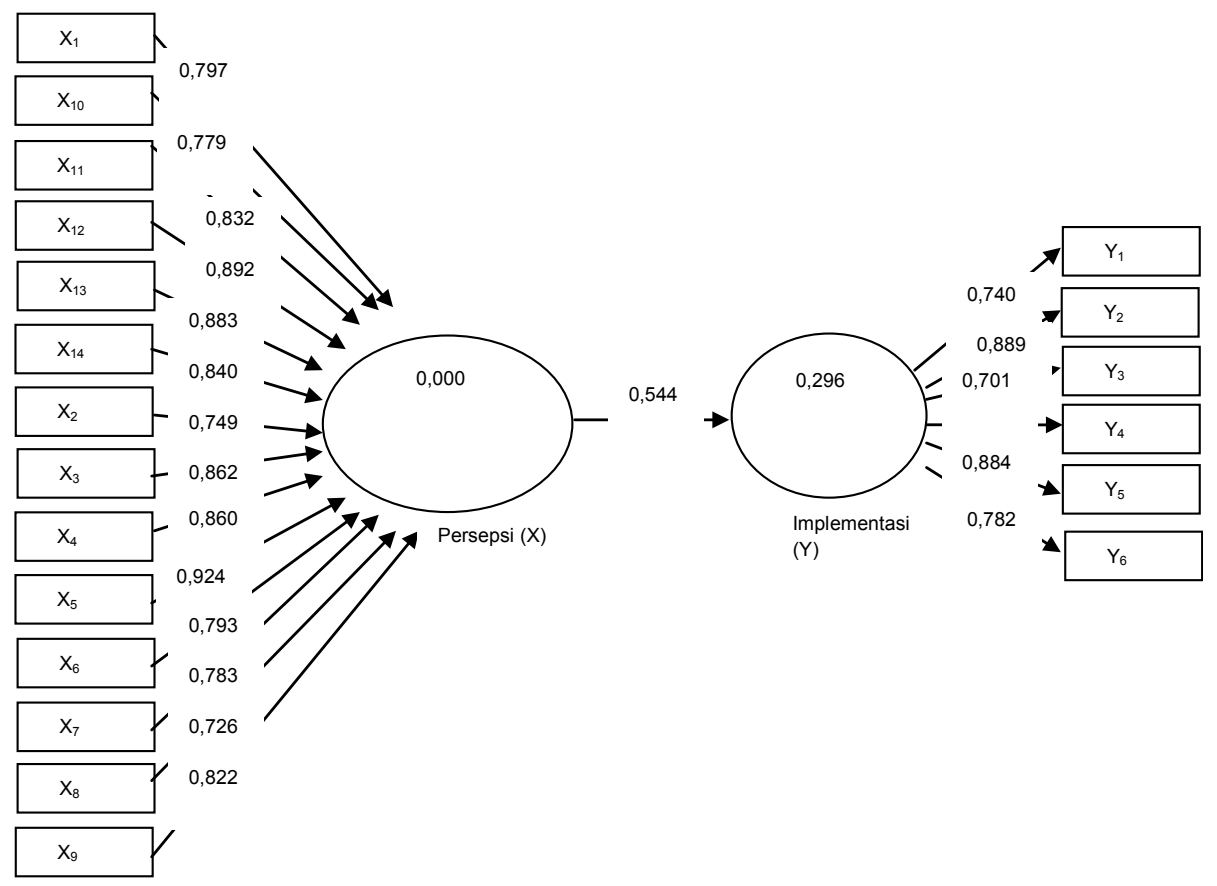

Gambar 2

Diagram jalur model lengkap

Koefisien Korelasi dan T Statistik

Koefisien korelasi merupakan angka yang menunjukkan derajat asosiasi atau keeratan hubungan antara variabel laten eksogen dengan variabel laten endogen. Berdasarkan hasil pengolahan data menggunakan SmartPLS diperoleh hasil seperti dapat dilihat pada tabel 5.

Tabel 5

Nilai koefisien korelasi dan T-statistik

\begin{tabular}{ccc}
\hline & Original Sample $(\mathrm{O})$ & T Statistics $(\mid$ O/STERR $)$ \\
\hline $\mathrm{X} \rightarrow \mathrm{Y}$ & 0,544 & 11,155 \\
\hline
\end{tabular}

Sumber: Hasil pengolahan data menggunakan SmartPLS

Nilai koefisien korelasi dan t-statistik yang tersaji pada tabel 5 dapat dijelaskan sebagai berikut:
1. Korelasi antara persepsi dengan implementasi adalah sebesar 0,544 dan termasuk dalam kategori hubungan yang sedang dikarenakan berada pada interval 
antara 0,40-0,599. Koefisien korelasi bertanda positif yang menunjukkan bahwa hubungan yang terjadi antara keduanya adalah searah, artinya semakin baik persepsi, akan berdampak pada peningkatakan kualitas implementasi proses pembelajaran.

2. Nilai t-statistik yang diperoleh adalah sebesar 11,155 dan lebih besar dari nilai t-kritis yang direkomendasikan yakni sebesar 1,96. Hasil tersebut menunjukkan bahwa terdapat hubungan yang sedang dan signifikan antara persepsi dengan implementasi proses pembelajaran.

\section{Koefisien Determinasi}

Koefisien determinasi merupakan angka yang menunjukkan besarnya kontribusi pengaruh yang diberikan oleh variabel laten eksogen terhadap variabel laten endogen. Berdasarkan hasil pengolahan data menggunakan software SmartPLS diperoleh hasil seperti dapat dilihat pada tabel 6 .

Tabel 6

Koefisien determinasi

\begin{tabular}{cc}
\hline & $R$ Square \\
\hline $\mathrm{X} \rightarrow \mathrm{Y}$ & 0,296 \\
\hline
\end{tabular}

Sumber: Hasil pengolahan data menggunakan SmartPLS

Pada tabel 6 dapat dilihat bahwa nilai $R$ Square yang diperoleh untuk pengaruh persepsi terhadap implementasi adalah sebesar 0,296 atau 29,6\%. Hasil tersebut menunjukkan bahwa persepsi memberikan kontribusi sebesar $\quad 29,6 \%$ terhadap implementasi.

\section{Uji Kecocokan Model (Goodnes of Fit/ GoF)}

Pengujian GoF ini bertujuan untuk

memvalidasi model secara keseluruhan menggunakan nilai Goodness of Fit (GoF) yang merupakan ukuran tunggal yang digunakan untuk memvalidasi performa gabungan antara model pengukuran dan model struktural. Nilai ini diperoleh dari akar rata-rata communality dikalikan dengan akar rata-rata $R$-square.

Berdasarkan Tabel 7 diperoleh ratarata nilai communality dan $R$-square yang selanjutnya akan dihitung dengan rumus berikut:

Tabel 7

\begin{tabular}{ccc}
\multicolumn{3}{c}{ Rata-rata communality dan r square } \\
\hline \multicolumn{1}{c}{ Communality } & $R$ Square \\
Y & 0.682 & 0.296 \\
Rata-rata & 0.655 & 0.296 \\
\hline
\end{tabular}

Sumber: Hasil pengolahan data menggunakan SmartPLS

$$
\begin{aligned}
& \text { GoF }=\sqrt{\overline{\operatorname{com}} \times \overline{R^{2}}} \\
& \text { GoF }=\sqrt{0.669 \times 0.296} \\
& \text { GoF }=0.445
\end{aligned}
$$

Oleh karena nilai GoF sebesar 0.445 lebih besar dari 0.36, maka dapat disimpulkan bahwa kualitas kecocokan model secara keseluruhan termasuk dalam kategori kuat (Ghozali, 2014:103), sehingga dapat disimpulkan bahwa hasil uji kecocokan model goodness of fit sudah tergolong kuat.

\section{Pengujian Hipotesis}

Untuk menguji signifikansi (kebermaknaan) pengaruh variabel laten eksogen terhadap variabel laten endogen, maka dilakukan pengujian hipotesis dengan uraian sebagai berikut: 


\section{Hipotesis I}

Rumusan hipotesis yang akan diuji adalah sebagai berikut:

$\begin{array}{rlr}\mathrm{H}_{0}: \gamma=0 \quad & \text { Persepsi tidak } & \text { berpengaruh } \\ & \text { signifikan } & \text { terhadap } \\ \text { implementasi } & \text { proses } \\ \text { pembelajaran di } & \text { ISBI } \\ & \text { Bandung pada } & \text { proses } \\ & \text { pembelajaran. } & \end{array}$

$\begin{array}{rlr}\mathrm{H}_{1}: \gamma \neq 0 & \text { Persepsi } & \text { berpengaruh } \\ & \text { signifikan } & \text { terhadap } \\ \text { implementasi } & \text { proses }\end{array}$

pembelajaran di ISBI
Bandung pada proses
pembelajaran.

Taraf signifikansi $(\alpha)$ yang digunakan adalah sebesar 0.05 atau $5 \%$.

Kriteria pengambilan keputusan:

1) Tolak $\mathrm{H}_{0}$ dan terima $\mathrm{H}_{1}$ jika nilai t-statistic $>$ t-kritis

2) Terima $\mathrm{H}_{0}$ dan tolak $\mathrm{H}_{1}$ jika nilai t-statistic $<\mathrm{t}$-kritis

Rangkuman hasil pengujian disajikan pada Tabel 8 .

Tabel 8

Pengujian hipotesis pengaruh persepsi terhadap implementasi proses pembelajaran

\begin{tabular}{cccccc}
\hline Model & Koefisien Jalur & t-statistics & t-kritis & Keputusan & Kesimpulan \\
\hline $\mathrm{X} \rightarrow \mathrm{Y}$ & 0.544 & 11.155 & 1.96 & $\mathrm{H}_{0}$ ditolak & Signifikan \\
\hline
\end{tabular}

Sumber: Hasil pengolahan data menggunakan SmartPLS

Pada Tabel 8 dapat dilihat bahwa nilai t-statistics yang diperoleh adalah sebesar 11.155 lebih besar dari 1.96. Daerah penolakan maupun penerimaan $\mathrm{H}_{0}$ dapat digambarkan seperti dapat dilihat pada Gambar 4.

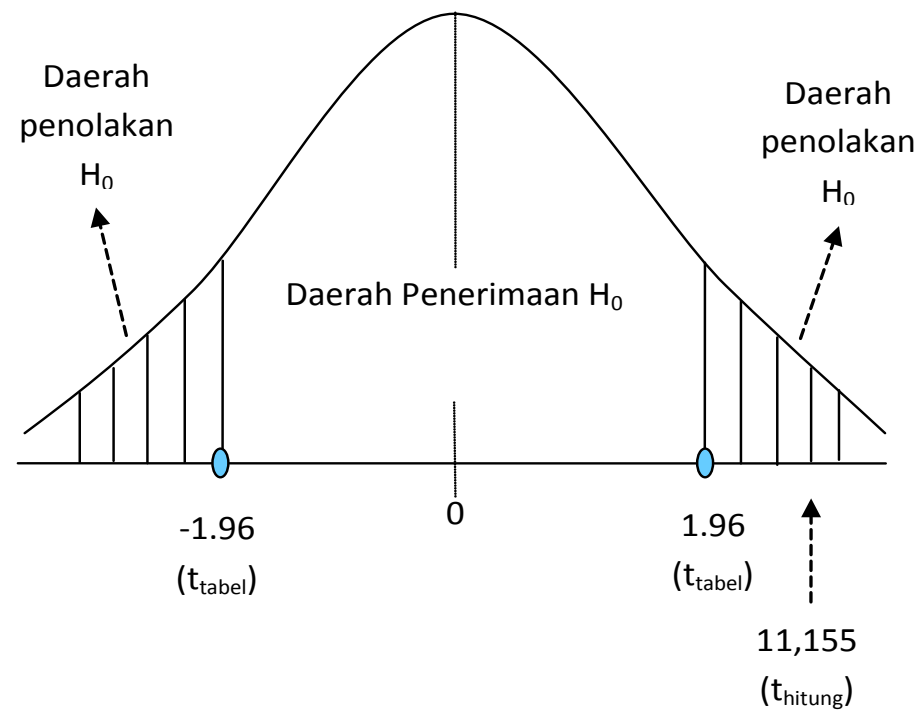

Gambar 4 Kurva pengujian hipotesis pengaruh persepsi terhadap implementasi proses pembelajaran

Pada Gambar 4 tampak nilai t-statistics sebesar 11.155 jatuh pada daerah penolakan $\mathrm{H}_{0}$ (t-statistics $>\mathrm{t}$-kritis) sehingga keputusan uji hipotesis adalah menolak $\mathrm{H}_{0}$ dan menerima $\mathrm{H}_{1}$. Hasil tersebut menunjukkan bahwa persepsi berpengaruh signifikan terhadap implementasi proses pembelajaran di ISBI Bandung pada proses pembelajaran.

Uraian berikutnya adalah tabulasi korelasi antara persepsi pada proses pembelajaran dengan profil responden. Pada Tabel 9 akan disajikan data korelasi profil responden dengan persepsi.

Berdasarkan hasil uji menggunakan chi square, diperoleh p-value untuk korelasi profil responden dengan persepsi, semua korelasi mempunyai nilai lebih besar dari 0,05 . Hal ini menunjukkan bahwa tidak terdapat hubungan yang signifikan antara profil responden dengan persepsi. Jika taraf 
Tabel 9

Korelasi profil responden dengan persepsi

\begin{tabular}{lcl}
\hline \multicolumn{1}{c}{ Profil Responden - Persepsi } & p value & Korelasi \\
\hline Jenis Kelamin - Persepsi & 0.512 & Tidak Signifikan \\
Usia - Persepsi & 0.531 & Tidak Signifikan \\
Status Pernikahan - Persepsi & 0.640 & Tidak Signifikan \\
Pendidikan Terakhir - Persepsi & 0.688 & Tidak Signifikan \\
Masa Kerja - Persepsi & 0.599 & Tidak Signifikan \\
Prodi - Persepsi & 0.091 & Tidak Signifikan \\
Jenjang Kepangkatan - Persepsi & 0.364 & Tidak Signifikan \\
Jabatan Selain TFA - Persepsi & 0.868 & Tidak Signifikan \\
Serdos - Persepsi & 0.148 & Tidak Signifikan \\
\hline
\end{tabular}

Keterangan : Signifikan jika v-palue $<0.05$

signifikansi $(\alpha)$ yang digunakan sebesar 0.10 atau $10 \%$ hanya satu nilai p-value yang lebih kecil dari 0.10 yakni untuk korelasi antara program studi (prodi) dengan persepsi, dan artinya terdapat hubungan yang signifikan antara prodi dengan persepsi.

\section{SIMPULAN}

Berdasarkan hasil analisis dan pembahasan yang telah dilakukan maka dapat ditarik beberapa simpulan sebagai berikut:

1. Faktor yang memberi pengaruh paling tinggi terhadap persepsi dosen mengenai standar mutu proses pembelajaran adalah faktor memerlukan standar mutu $\left(\mathrm{x}_{5}\right)$ yakni sebesar $92,4 \%$.

2. Faktor profil responden seperti jenis kelamin, usia, status pernikahan, pendidikan, masa kerja, unit kerja/prodi, jenjang kepangkatan, jabatan selain TFA, dan tunjangan sertifikasi dosen tidak berpengaruh nyata terhadap persepsi dosen mengenai standar mutu proses pembelajaran.

3. Persepsi berpengaruh signifikan terhadap implementasi proses pembelajaran di ISBI Bandung dengan kontribusi yang diberikan sebesar 29,6\%.

\section{DAFTAR RUJUKAN}

Ahuja V. 2013. Application of quality management systems in higher education. International Journal of Applied Services Marketing Perspective. 2(2): 417-421.

Azwar S. 2004. Reliabilitas dan Validitas. Yogyakarta (ID): Pustaka Pelajar.

Ghozali I. 2011. Aplikasi Analisis Multivariate dengan Program IBM SPSS 19. Semarang (ID): Badan Penerbit Universitas Diponegoro.

Irawan A. 2015. Analisis faktor-faktor yang memengaruhi kinerja Pegawai Negeri Sipil (PNS) di Direktorat Jenderal Pendidikan Tinggi [tesis]. Bogor (ID): Institut Pertanian Bogor.

[Kemendikbud] Kementerian Pendidikan dan Kebudayaan. 2014b. Peraturan Menteri Pendidikan dan Kebudayaan no 50 tahun 2014 tentang sistem penjaminan mutu pendidikan tinggi. Jakarta (ID): Kemendikbud

Mergen E, Grant D, Widrick SM. 2000. Quality management applied to higher education. Jounal of Total Quality Management. 11(3): 345-352.

Narimawati U. 2007. Riset Manajemen Sumber Daya Manusia Aplikasi Contoh dan Perhitungannya. Jakarta (ID): Agung Media.

Owlia MS, Aspinwall EM. 2015. TQM in higher education - a review. Journal of Business And EconomicsManagement. 14(5): 527-543.

Pemerintah Republik Indonesia. 2012. Undang-Undang no 12 tahun 2012 tentang pendidikan tinggi. Jakarta (ID): Sekretariat Negara. 
Richardson S, Nwankwo S, Richardson B. 1995. Strategic Issues for Higher Education Strategists in the U.K.: A Political Contingency Perspective. International Journal of Public Sector Management. 8 (6): 7-16.

Sugiarto, Siagian D, Sunaryanto LT, Oetomo DS. 2001. Teknik Sampling. Jakarta (ID): PT. Gramedia Pustaka Utama.

Sugiyono. 2014. Metode Penelitian Kuantitatif Kualitatif dan R\&D. Bandung (ID): Alfabeta.

Walgito B. 2010. Pengantar Psikologi Umum. Yogyakarta (ID): Penerbit Andi.

Yamin S, Kurniawan H. 2009. SPSS Complete Teknik Analisis Statistik Terlengkap dengan Software SPSS. Jakarta (ID): Salemba Infotek. 